\title{
How to manage left ventricular embolization of the transcatheter valve
}

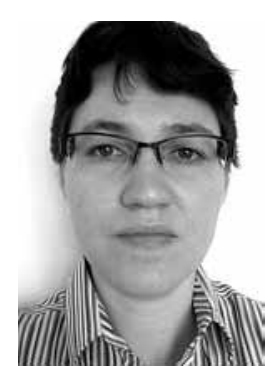

\author{
Júlia Čanádyová모 ${ }^{1}$ Aleš Mokráček ${ }^{1}$, Ladislav Pešl ${ }^{2}$, Vojtěch Kurfirst ${ }^{1}$ \\ ${ }^{1}$ Department of Cardiac Surgery, Hospital České Budějovice, Czech Republic \\ 2Department of Cardiology, Hospital České Budějovice, Czech Republic
}

Kardiochirurgia i Torakochirurgia Polska 2015; 12 (1): 53-55

\begin{abstract}
Transcatheter aortic valve implantation is a treatment alternative for high-risk patients with severe aortic stenosis who are not eligible for conventional open aortic valve replacement. We describe a case of a rare but serious complication in the form of ventricular embolization of an Edwards Sapien-XT aortic valve following its transapical implantation. The valve was successfully captured and reimplanted into the aortic annulus, which did not require conversion to median sternotomy or use of extracorporeal circulation.
\end{abstract}

Key words: transcatheter valve implantation, ventricular valve embolization.

\section{Introduction}

Transcatheter aortic valve implantation (TAVI) is a minimally invasive and safe treatment alternative for severe symptomatic aortic valve stenosis in high-risk patients who are considered unsuitable for open heart surgery due to their increased risk profiles [1].

Based on the results of the PARTNER trial, TAVI procedures have been associated with higher incidence of vascular complications, embolic stroke, conduction irregularities, and paravalvular leakage. One rare but serious complication is valve embolization due to its malposition in the aortic annulus: distally into the aorta or into the left ventricle [1].

\section{Case report}

We present the case of an 82-year-old man with severe symptomatic aortic valve stenosis with an indexed aortic valve area of $0.36 \mathrm{~cm}^{2}$, mean pressure gradient of $35 \mathrm{mmHg}$, and left ventricular ejection fraction of $37 \%$. The institution's Heart Team decided that the patient was not suitable for conventional aortic valve replacement because of his high risk profile. The patient's preoperative logistic EuroSCORE was $50.86 \%$, taking into consideration

\section{Streszczenie}

Przezcewnikowe wszczepienie zastawki aortalnej stanowi alternatywę dla pacjentów wysokiego ryzyka z ciężką stenozą aortalną, którzy nie kwalifikują się do tradycyjnej wymiany zastawki aortalnej przeprowadzanej na otwartym sercu. Poniższa praca opisuje przypadek rzadkiej, ale poważnej komplikacji w postaci embolizacji zastawki aortalnej Edwards Sapien-XT ${ }^{\mathrm{TM}}$ po jej przezkoniuszkowym wszczepieniu oraz udanego uchwycenia i reimplantacji tejże zastawki do pierścienia aortalnego, które nie wymagały konwersji do sternotomii pośrodkowej ani zastosowania krążenia pozaustrojowego.

Słowa kluczowe: przezcewnikowe wszczepienie zastawki, komorowa embolizacja zastawki.

his age, gender, coronary artery disease with previous cardiac surgery, as well as other comorbidities such as chronic obstructive pulmonary disease, moderate left ventricular dysfunction, left atrial thrombus, and severe pulmonary hypertension (PA > $55 \mathrm{mmHg}$ ). In 2002, the patient underwent coronary artery bypass surgery with a patent venous bypass on the left obtuse artery. Before the TAVI procedure, the patient underwent elective angioplasty and stenting of a $90 \%$ stenosis of the left anterior descending branch with a drug-eluting stent (COMBO, OrbusNeich, Netherlands).

The primary method of measuring the aortic annular diameter used in our department is transesophageal echocardiography. The aortic annulus was $25 \mathrm{~mm}$ in diameter, and so the largest prosthesis $(29 \mathrm{~mm})$ was selected. The aortic valve was tricuspid with a fusion of the left and right cusps and a moderate amount of calcification in the annulus and leaflets. These findings were confirmed by computed tomography (CT), which demonstrated moderate calcification of the aortic valve and confirmed the annulus size to be $25 \mathrm{~mm}$. Obstruction of the calcified native valve was associated with a mean pressure gradient of $25 \mathrm{mmHg}$. Dobutamine stress echocardiography provides useful information concerning contractile reserve in pa-

Address for correspondence: Júlia Čanádyová, MD, Hospital České Budějovice, Boženy Němcové 54, 37001 České Budẽjovice, Czech Republic, phone: 00420387874202, e-mail: canadyova.julia@gmail.com 
tients with low pressure gradients across the aortic valve and left ventricular dysfunction. According to the dobutamine stress echocardiogram, the contractility of all heart segments was improved, ejection fraction increased from $31 \%$ to $37 \%$, and the mean pressure gradient rose from $25 \mathrm{mmHg}$ to $35 \mathrm{mmHg}$.

The transapical approach was chosen because the CT examination had revealed significant tortuosity of the iliac vessel and the presence of atherosclerotic plaques in the thoracic aortic wall and arch. The transapical approach is preferred in our department because it enables more intuitive manipulation of the deployment device system within the short distance. In cases where atherosclerotic plaques are present in the aortic wall, this approach also enables the avoidance of manipulation into the aorta and embolization from the plaques.

The procedure was performed under general anesthesia. The valve was inserted transapically in a standard fashion. Aortic balloon valvuloplasty (Fig. 1A) was conducted to split the valve commissures during rapid pacing. Following the balloon valvuloplasty, a stented $29 \mathrm{~mm}$ Edwards Sapien $\mathrm{XT}$ valve (Edwards Lifesciences, Irvine, CA) crimped onto a delivery balloon was advanced over a wire into the aortic annulus during rapid ventricular pacing (Fig. 1B). When the positioning was considered correct, the prosthesis was released, and the device was initially expanded to its full diameter of $29 \mathrm{~mm}$ (Fig. 1C).

The valve was embolized into the left ventricle after a few ventricular contractions (Fig. 2D). The stiff wire was left in place in order to prevent valve rotation and left ventricular outflow tract obstruction. We decided to reinsert the same deployment balloon over the wire and partially inflated the balloon within the valve between the two marks on the balloon. The balloon with the captured valve was then pushed into the aortic annulus, and its position was secured by slight balloon overdilation.

A second $29 \mathrm{~mm}$ Edwards Sapien valve was immediately implanted higher in the aorta, overlapping the first prosthesis in order to achieve a stable position of the first prosthesis, prevent valve embolization, and also provide effective paravalvular sealing (Figs. 2E-F). Control transesophageal echocardiography showed good prosthesis function without any central or paravalvular insufficiency. There was no obstruction of the coronary ostia, only an atrioventricular block which required external pacing.

Due to hypotension during the delivery of the second valve, pharmacologic resuscitation with adrenaline administration and heart massage for a few minutes was started. After hemodynamic recovery and stabilization, a thoracic drain was placed into the left pleural cavity. The thoracotomy wound was sutured in standard fashion, and the patient was transferred to the intensive care unit in a hemodynamically stable condition with external pacing. The postoperative course was uneventful, without neurological deficiency; left pleural effusion was present, but decreased after corticosteroid therapy. On the fifth postoperative day, the patient underwent elective pacemaker implantation.

\section{Discussion}

Transcatheter aortic valve embolization is a rare but serious complication. It occurs due to poor positioning of the transcatheter heart valve or valve ejection after effec-
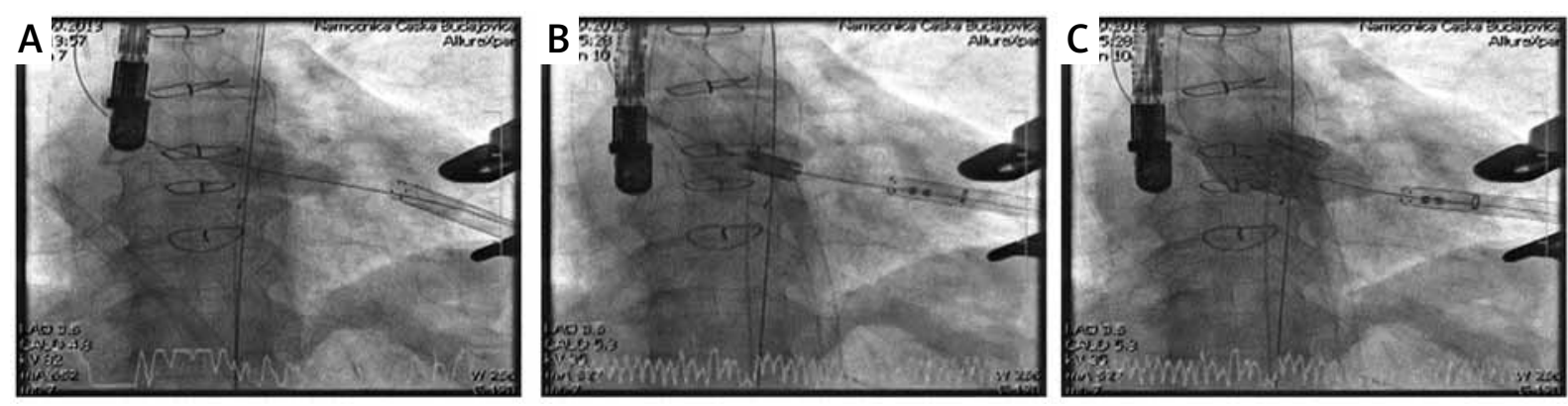

Fig. 1. A) Balloon valvuloplasty. B) Valve introduction. C) Valve release and expansion
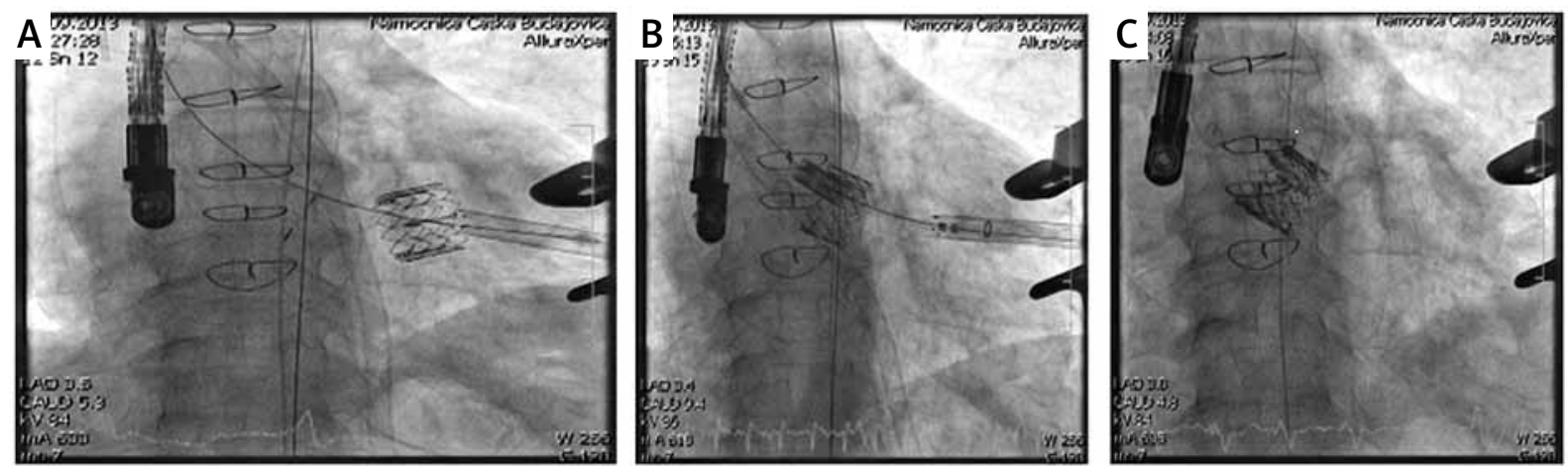

Fig. 2. A) Valve embolization into the left ventricle. B) Reinsertion of the first valve and second valve implantation (valve-in-valve). C) Valve-in-valve: definitive result 
tive ventricular contraction. Embolization typically occurs immediately after deployment of the valve, which is most often repositioned distally into the aorta. Valve embolization rates have been reported to range from $0.5 \%$ to $8 \%$ [2]. The outcome of a distal aortic embolization of the Edwards Sapien valve can remain positive if it is managed appropriately. The embolized prosthesis in this case was repositioned into the aortic arch, and there was no need for its removal. Ventricular embolization of the Edwards Sapien valve is a rare and severe complication of TAVI, and it typically necessitates conversion to median sternotomy [3].

The common reasons for embolization are 1) mild valve calcification, 2) valve undersizing, 3) malposition in the aortic annulus, and 4) inadequate ventricular pacing during valve deployment resulting in an increase in stroke volume which ejects the valve. Less common causes include prior mitral valve replacement when the struts of the bioprosthesis displace the valve-balloon toward the aorta and inadequate or missed valvuloplasty [2].

Astarci et al. described a case employing the transapical access route to explant an Edwards Sapien valve wherein percutaneous femoral extracorporeal circulation was instituted immediately after embolization into the left ventricle occurred [3].

Dumonteil et al. described the first case of successful reimpaction of a valve embolized into the left ventricle [4].

When embolization does occur, it is important to maintain a coaxial wire within the prosthesis in order to prevent it from becoming inverted and obstructing aortic flow. Repositioning can be achieved by withdrawing the prosthesis on an inflated valvuloplasty balloon to a secure position in the aortic annulus. Slight overdilation may be helpful in fixing the valve within the annulus [2].

The valve-in-valve technique is a useful interventional option for managing device malposition that can occur during TAVI. This technique may secure a stable valve position and prevent paravalvular leakage [5].

\section{Conclusions}

The aim of this case report was to highlight a treatment alternative for a seriously life-threatening complications such as left ventricular embolization of a transcatheter prosthesis without conversion to sternotomy or extracorporeal circulation. Capturing the valve in a balloon and repositioning it from the left ventricle into the annulus may be the best first option to be attempted in this situation.

\section{Disclosure}

Authors report no conflict of interest.

\section{References}

1. Vahanian A, Alfieri OR, Al-Attar N, Antunes MJ, Bax J, Cormier B, Cribier A, De Jaegere P, Fournial G, Kappetein AP, Kovac J, Ludgate S, Maisano F, Moat N, Mohr FW, Nataf P, Pierard L, Pomar JL, Schofer J, Tornos P, Tuzcu M, van Hout B, von Segesser LK, Walther T. Transcatheter valve implantation for patients with aortic stenosis: a position statement from the European Association of Cardio-Thoracic Surgery (EACTS) and the European Society of Cardiology (ESC), in collaboration with the European Association of Percutaneous Cardiovascular Interventions (EAPCI). Eur J Cardiothorac Surg 2008; 34: 1-8

2. Tay ELW, Gurvitch R, Wijeysinghe N, Nietlispach F, Leipsic J, Wood DA, Yong G, Cheung A, Ye J, Lichtenstein SV, Carere R, Thompson C, Webb JG. Outcome of patients after transcatheter aortic valve embolization. JACC Cardiovasc Interv 2011; 4: 228-234.

3. Astarci P, Desiron Q, Glineur D, El Khoury G. Transapical explantation of an embolized transcatheter valve. Interact Cardiovasc Thorac Surg 2011; 13: $1-2$.

4. Dumonteil N, Marcheix B, Grunenwald E, Roncalli J, Massabuau P, Carrié D. Left ventricular embolization of an aortic balloon-expandable bioprosthesis: balloon capture and reimpaction as an alternative to emergent conversion to open-heart surgery. JACC Cardiovasc Interv 2013; 6: 308-310.

5. Ussia GP, Barbanti M, Ramondo A, Petronio AS, Ettori F, Santoro G, Klugmann S, Bedogni F, Maisano F, Marzocchi A, Poli A, Napodano M, Tamburino $C$. The valve-in-valve technique for treatment of aortic bioprosthesis malposition: an analysis of incidence and 1-year clinical outcomes from the Italian CoreValve registry. J Am Coll Cardiol 2011; 57: 1062-1068. 